\title{
Assessment of polycyclic aromatic hydrocarbons in biochar and biochar-amended agricultural soil from Southern Spain
}

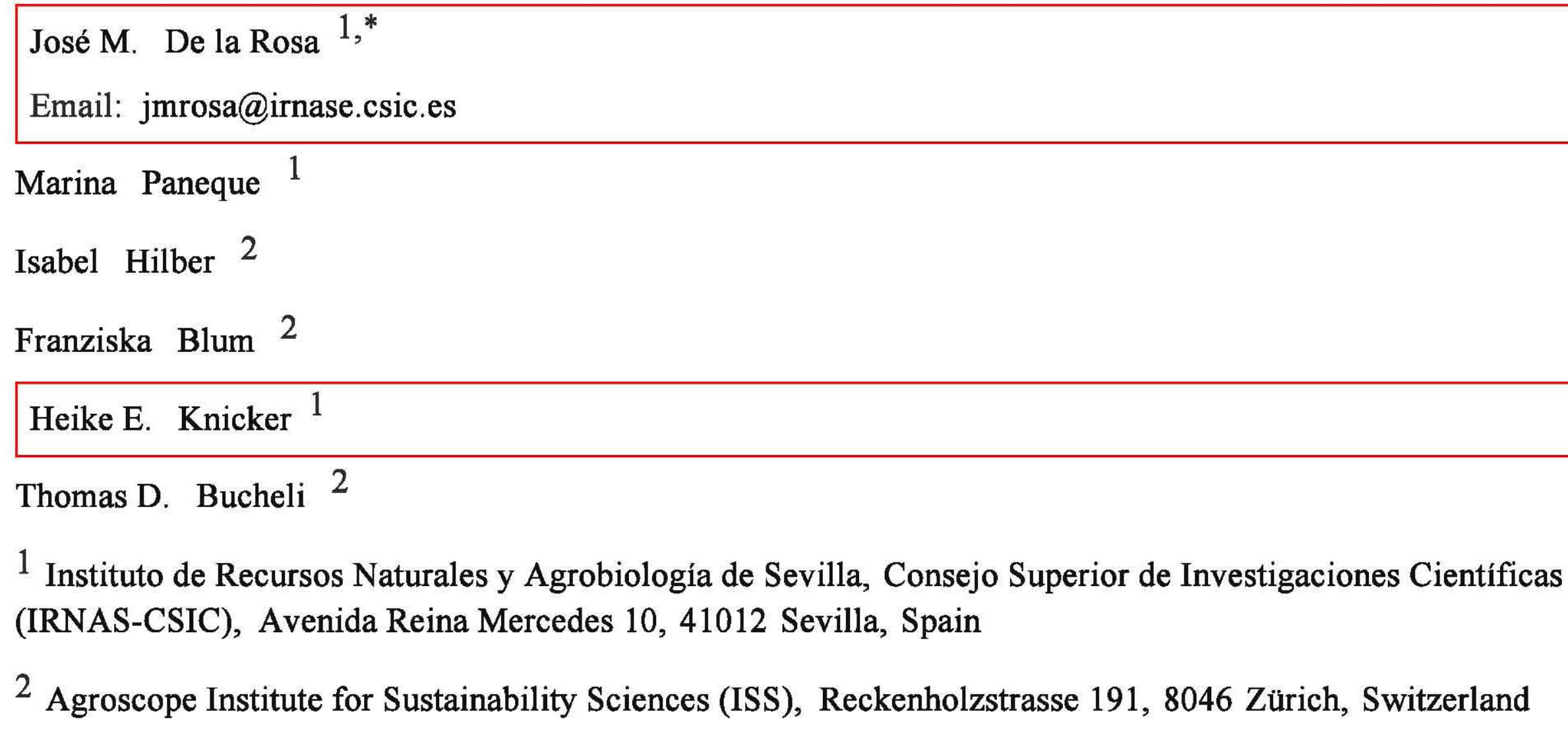


The goal of this study was to determine if the application of four biochars produced from different feedstock leads to soil contamination with the 16 US Environmental Protection Agency (EPA) polycyclic aromatic hydrocarbons (PAHs) in biochar-amended pots incubated under greenhouse conditions.

\section{Materials and methods}

The PAHs were extracted by Soxhlet and quantified by gas chromatography mass spectrometry in the biochars and in biochar-amended Calcic Cambisols on which Lolium perenne was grown under greenhouse conditions during 79 days. Three of the used biochars were produced by pyrolysis at $620^{\circ} \mathrm{C}$ from wood chips, paper sludge, and sewage sludge, respectively. The fourth biochar was produced from old grapevine wood by the traditional kiln method.

\section{Results and discussion}

The Soxhlet extraction of the $\Sigma^{16}$ PAHs of pure biochars yielded between $959 \pm 62$ (sewage sludge biochar) and $2613 \pm 1380 \mu \mathrm{g} \mathrm{kg}^{-1}$ (pine wood biochar) dry mass. The lowest abundance of PAHs of sewage sludge biochar is consistent with its very low content of organic carbon and the abundance of ashes. The PAH concentration of the wood biochar produced by kiln was six times higher than the wood biochar produced by fast pyrolysis, indicating that the biochar production process significantly affected the PAH levels. The unamended soil showed PAH levels typically for non-polluted soils $\left(\Sigma^{16} \mathrm{PAHs}=59 \pm 4 \mu \mathrm{g} \mathrm{kg}^{-1}\right)$. Addition of $10 \mathrm{t}$ biochar ha ${ }^{-1}$ soil resulted in a lower increase of the 16 PAHs than expected for wood and paper sludge biochars, whereas for the soils amended with kiln wood biochar, the content of PAHs increased up to a factor of 10. Amendments of 20 and $40 \mathrm{tha}^{-1}$ increased PAH concentrations to values on the same order of magnitude than the predicted ones, except for pine wood biochar, where the concentrations were ten times greater than expected. The major divergences were found for high-molecular-weight PAHs. 


\section{Conclusions}

The production process of biochar affected significantly their PAH levels. The material carbonized in traditional kilns contained the greatest amounts of PAHs. Sampling procedures for biochar-amended soils should be carefully described for future legislation guidelines to guarantee quality biochar application.

\section{Keywords}

Pyrolysis

Pot experiments

Kiln

Polycyclic aromatic hydrocarbons

Soxhlet extraction

Soil amendment

Responsible editor: Rongliang Qiu

\section{Introduction}

The application of biochar to soil is proposed as a valid and sustainable tool for managing agricultural and urban wastes and to produce added value products. Biochar may act as a soil conditioner, enhancing plant growth by supplying and, more importantly, retaining nutrients and by providing other services such as improving soil physical and biological properties (Ogawa and Okimori 2010). In addition, biochar is a valuable animal feed supplement and conditioner in stables or manure (Gerlach and Schmidt 2011). Various feedstock, such as organic waste derived from agriculture and forestry or urban wastes including sewage sludge, can be used for biochar production. Their chemical composition as well as the production conditions will determine the properties and 
composition of produced biochars (Zhao et al. 2013). Thus, bearing in mind that biochar composition and characteristics can largely vary, the focus has to be oriented on guaranteeing the safe agricultural use of biochar. However, biochar policy demands are at an early stage of development, and their regulatory and testing requirements are still being defined by international initiatives such as the European Biochar Certificate (EBC 2012 ) or the International Biochar Initiative (IBI 2013). Both pay particular attention to the formation and accumulation of polycyclic aromatic hydrocarbons (PAHs) during pyrolysis (Fagernäs et al. 2012)

These persistent organic pollutants are highly condensed aromatic structures formed during biochar production due to incomplete combustion (pyrolysis step) (Bucheli et al. 2015; Ledesma et al. 2002). The sort and amount of such compounds in the final biochar are greatly influenced by the pyrolysis process. PAHs are included in the European Union and US Environmental Protection Agency (US EPA) priority pollutant lists because they represent the largest group of compounds that are mutagenic, carcinogenic, and teratogenic (ECR 2006; US EPA 2002). These PAHs may enter the environment when biochar is applied as soil conditioner. Thus, several international institutions agreed to a range of maximum allowed values for the quantity of the 16 US EPA PAHs in biochar. They were set under 4 and $12 \mathrm{mg} \mathrm{kg}^{-1}$ dry weight (dw) for premium and regular biochars, respectively, according to the European Biochar Certificate (EBC) (EBC 2012;2015), and in the range of 6 to $20 \mathrm{mg} \mathrm{kg}^{-1} \mathrm{dw}^{2}$ according to the International Biochar Initiative (IBI) (IBI 2013). The Joint Research Centre of the DirectorateGeneral for the Environment of the European Union established a preliminary threshold of $6 \mathrm{mg} \mathrm{kg}^{-1} \mathrm{dw}$ of PAHs for biowaste (which would include biochar material) allowed to be used in agriculture (Estrada de Luís and Gómez Palacios 2013). Liu et al. (2014) reported that biochar amendments could be a successful tool to dissipate PAH by bacteria in contaminated soils. Li et al. (2014), on the other hand, reported that activated biochar could effectively bind PAHs. This would reduce the risk of PAH contamination when biochar is applied in agriculture. Anyway, plants grown on PAH-contaminated soils can accumulate PAHs, although the mechanism of uptake is poorly understood (Rogovska et al. 2012). Due to the irreversibility of biochar application, the risk of concomitant contamination should not be neglected. Total concentrations of PAHs in biochar are currently still the focus of many researchers, engineers, and authorities, in particular because of respective legally binding guide values (among others: Keiluweit et al. 2012; Fabbri et al. 2013; Brennan et al. 2014; Bucheli et al. 2015). In addition, 
policymakers of numerous countries are working on appropriate thresholds to limit the presence of pollutants in biochars in relation to their use. These cutoff values will include not only PAHs but also heavy metals and other organic pollutants such as polychlorinated dibenzo-p-dioxins, furans, or polychlorinated biphenyls. Regardless of the interest of legislators, very few evaluations of biochar for their content of PAHs or other organic compounds are available (Fabbri et al. 2013; Oleszczuk et al. 2014; Bucheli et al. 2015). Even less information exists about the fate of PAHs from biochar after their application to agricultural soils. Fabbri et al. (2013) assessed the PAHs for one soil amended with a reference biochar $(1.16 \% w / w)$. Although they did not assess the impact of incubation time or plant growth, they observed that the measured concentrations of specific PAHs in the soil differed by $+60 \%$ for benzo $[a]$ anthracene $[\mathrm{BaA}]$ to $-51 \%$ for benzo $[k]$ fluoranthene $[\mathrm{BkF}]$ from the amounts which were originally added with the biochar.

AQ1

$\mathrm{AQ2}$

Another challenge which still needs to be addressed is the high variability in the analytical methodology applied for PAH assessment in biochar samples. This includes sample pretreatments (grinding, milling, sieving with different cutoffs, different range of sample weight), extraction procedures (Soxhlet, accelerated solvent extraction, soxtherm, ultrasonication, microwave, etc.), and the used solvents (toluene, hexane, cyclohexane, dichloromethane, acetonitrile, acetone, and mixtures of different proportions) (Brennan et al. 2014; Bucheli et al. 2015; Fabbri et al. 2013; Keiluweit et al. 2012; Wang et al. 2013). Rogovska et al. (2012) and González-Pérez et al. (2014) determined the PAHs in soils by analytical pyrolysis, which does not apply any solvent extraction and does not allow quantification. Thus, this approach has yet to be aligned with traditional exhaustive, wet chemical analytical methods to account for the special requirements for the analysis of biochars. Hilber et al. (2012) studied the effect of different solvents and extraction times and methods for the quantification of PAHs in biochars. Based on this, they were able to develop a methodology which greatly improved the efficiency of the PAH extraction from biochar samples and their quantification. However, to elucidate the impact of biochar on soil quality, a more systematic assessment of concentration and fate of their PAHs in soils is needed. 
The intention of the present study was to elucidate a potential hazardous impact of biochar-derived PAHs in agricultural soils. To reach our goal, we used four biochars which were produced from different feedstock and conditions and added them in varying doses to material from a typical arable soil of the Guadalquivir river valley (De la Rosa 1984), on which Lolium perenne was grown in pots under greenhouse conditions. The authors of this study are conscious of the limitations of extrapolating results from pot experiments to field studies; nevertheless, it is necessary to perform detailed studies under controlled conditions to achieve a high level of certainty that adding biochar to agricultural soils will imply a minimum risk for health.

\section{Material and methods}

\subsection{Biochar samples}

Three of the biochars were provided by the European Ring Trial, organized by the Biochar COST action TD1107 "Biochar as option for sustainable resource management." These biochar materials were produced from wood chips, paper sludge, and sewage sludge, respectively (samples w-bc, ps-bc, and ss-bc) by applying technical pyrolysis by the companies Swiss Biochar, Sonnenerde $\mathrm{GmbH}$, and Pyreg, respectively. The controlled pyrolysis process was carried out under similar conditions (temperature increasing from 20 to $500-620^{\circ} \mathrm{C} ; 20$-min pyrolysis time; water content of $30 \%$ dry mass). The fourth biochar sample was provided by Bodegas Torres Company (Spain) and was made from old grapevine wood by using the traditional carbonization method in kilns (kiln stack wood biochar ( $\mathrm{kw}-\mathrm{bc})$ ). After the pyrolysis process, all samples were homogenized and oven-dried at $40{ }^{\circ} \mathrm{C}$ for $72 \mathrm{~h}$. In the case of kw-bc, due to the big size and heterogeneity of the fragments, the biochar was crushed and sieved $(<1 \mathrm{~cm})$. Subsequently, all samples were kept in sealed plastic bags and maintained at $4{ }^{\circ} \mathrm{C}$ until they were used. Subsequent analysis supported that this approach was sufficient to avoid chemical and physical alterations. A detailed characterization of physical and chemical properties of these biochars is given in Table 1. Samples w-bc, ps-bc, and kw-bc showed high $\mathrm{C}$ content and comparable elemental composition, $\mathrm{pH}$, water holding capacity, and ash content (De la Rosa et al. 2014). However, composition and characteristics of ss-bc (produced from sewage 
sludge) were drastically different. In fact, this sample should not be considered a biochar but a pyrogenic carbonaceous material according to the $\mathrm{EBC}$ guidelines $(\mathrm{H} / \mathrm{C}$ ratio should be $<0.7 ; \mathrm{O} / \mathrm{C}$ ratio $<0.4 ; \mathrm{C}$ content higher than $50 \%$ of the dry mass (EBC 2012)).

\section{Table 1}

Macroelemental analysis $(\mathrm{C}, \mathrm{H}, \mathrm{N}, \mathrm{O})$ and physicochemical properties of the biochars studied and of the soil used for the incubatior

\begin{tabular}{|c|c|c|c|c|c|c|c|c|c|c|c|}
\hline & \multicolumn{3}{|c|}{ Production details } & \multicolumn{7}{|c|}{ Elemental analysis $(\mathrm{C}, \mathrm{H}, \mathrm{N}, \mathbf{O})$} & $\mathbf{P}$ \\
\hline Sample & $\begin{array}{l}\text { Time } \\
(\min )\end{array}$ & $\begin{array}{c}\text { Temperature } \\
\left({ }^{\circ} \mathrm{C}\right)\end{array}$ & Methodology & $\mathrm{C}_{(-1}$ (g kg & $\mathbf{H}_{-1}(\mathbf{g} \mathbf{~ k g}$ & $N_{-1}^{(\mathbf{g}} \mathbf{~ k g}$ & $\mathrm{O}_{-(\mathrm{g})} \mathrm{kg}$ & $\mathrm{H} / C_{\mathrm{at}}$ & $\mathbf{O} / C_{\mathrm{at}}$ & $\mathbf{C} / \mathbf{N}$ & p. \\
\hline Wood bc & 20 & $20-620$ & $\begin{array}{l}\text { Rotary screw, } \\
\text { pyrolysis }\end{array}$ & 757 & 18 & 3 & 116 & 0.3 & 0.1 & 252 & 10.4 \\
\hline $\begin{array}{l}\text { Paper } \\
\text { sludge bc }\end{array}$ & 20 & $20-500$ & $\begin{array}{l}\text { Rotary screw, } \\
\text { pyrolysis }\end{array}$ & 509 & 20 & 14 & 206 & 0.5 & 0.3 & 37 & 10.4 \\
\hline $\begin{array}{l}\text { Sewage- } \\
\text { sludge bc }\end{array}$ & 20 & $20-600$ & $\begin{array}{l}\text { Rotary screw, } \\
\text { pyrolysis }\end{array}$ & 179 & 15 & 20 & 92 & 1.0 & 0.4 & 9 & 6.7 \\
\hline $\begin{array}{l}\text { Grapevine } \\
\text { wood bc }\end{array}$ & $>60$ & unknown & $\begin{array}{l}\text { Kiln } \\
\text { pyrolysis }\end{array}$ & 764 & 29 & 6 & 134 & 0.4 & 0.2 & 127 & 10.3 \\
\hline Soil & & & - & $\begin{array}{l}20(7 \\
\text { OC) }\end{array}$ & 3 & 1 & & & & 7 & 8.6 \\
\hline
\end{tabular}

Adapted from De la Rosa et al. (2014)

$S S A_{B E T}$ specific surface area according to Brunauer-Emmett-Teller (BET) equation, $b c$ biochar, $S D$ standard deviation. 


\subsection{Incubation of biochar-amended soils}

The soil used for the incubation experiment derived from the Ah horizon of a Calcic Cambisol (IUSS 2014), from "La Hampa" experimental station of the "Instituto de Recursos Naturales y Agrobiología de Sevilla" (SW Spain; $\left.37^{\circ} 21.32^{\prime} \mathrm{N}, 6^{\circ} 4.07^{\prime} \mathrm{W}\right)$.

The soil material was dried and sieved $(<2 \mathrm{~mm})$. Small branches, fresh mosses and plant remains, and roots were removed manually. Finally, the soil material was homogenized and stored at $4{ }^{\circ} \mathrm{C}$ during $24 \mathrm{~h}$ before being transferred to the pots. The composition and properties of the used soil are summarized in Table 1 . The fine earth contained $20 \mathrm{~g} \mathrm{C} \mathrm{kg}^{-1}$ of which $7 \mathrm{~g} \mathrm{~kg}^{-1}$ is attributed to organic carbon (OC) and $1 \mathrm{~g} \mathrm{~N} \mathrm{~kg}^{-1}$. Its pH in water was 8.6, and its water holding capacity (WHC) and ash content were 46 and $95.2 \% \mathrm{dw}$, respectively. Comparable physical and chemical characteristics for typical arable Cambisols of the Guadalquivir river valley have been previously reported by Mudarra Gómez (1988) and De la Rosa (1984)

The pots for the incubation experiment were prepared as follows: The bottom of the $250-\mathrm{mL}$ round plastic containers was perforated to allow leaching of surplus water during the experiment. In each pot, $125 \mathrm{~g}$ of soil was covered with a soil-biochar mixture. The latter was prepared by adding $1.10,2.20$, and $4.40 \mathrm{~g}$, equivalent to 10 , 20 , and $40 \mathrm{t} \mathrm{ha}^{-1}$ of each biochar, respectively, with additional $25 \mathrm{~g}$ of soil. In total $150 \mathrm{~g}$ of soil was used per pot on which 40 certified grass seeds (L. perenne, ILURO seeds company, Spain) were planted. L. perenne was used as a representative of an ubiquitously growing grass species which can easily be cultured in the frame of small-size pot experiments (De la Rosa et al. 2014). For each application rate and biochar, four replicates were prepared $(n=$ 4). Additionally, pots without any biochar amendment were prepared in a similar way than previously described and used as control $(n=6)$. After adjusting the soil humidity to 55-60\% of the maximum WHC, the pots were placed into a greenhouse at $26^{\circ} \mathrm{C}$ and 14-h light day ${ }^{-1}$ for 79 days. No mineral nutrient solution was added. The amount of regularly applied water accounted to $166 \mathrm{~L} \mathrm{~m}^{-2}$ for the entire experiment, which is similar to the annual average precipitation in this region $\left(750 \mathrm{~L} \mathrm{~m}^{-2}\right.$ year $\left.{ }^{-1}\right)$. After incubation, plant yield biomass was removed, cylinder pots were divided into four symmetrical sectors, and composite soil samples were prepared by combining 
three quartets taken from three different replicates. The soil material for PAH analysis was dried at $40{ }^{\circ} \mathrm{C}$ for $24 \mathrm{~h}$, sieved $(<2 \mathrm{~mm})$, homogenized, and stored in glass containers at $-20^{\circ} \mathrm{C}$.

\section{Analytical work: PAH extraction and quantification procedure}

The procedure applied was based on that reported by Bucheli et al. (2004) and Hilber et al. (2012). Briefly, pure biochar, biochar-amended soils, and control soils were dried, grinded $(0.75 \mathrm{~mm})$, homogenized (Turbula ShakerMixer Bachofen AG; Muttenz, Switzerland), and stored in amber glass at a dry place. Prior to extractions, samples were spiked with $20 \mu \mathrm{L}$ of toluene containing $200 \mathrm{ng}$ of each of the individual PAH internal standards.

To determine the total concentrations, dry samples ( $1.0 \mathrm{~g}$ for soils and $0.2-0.4 \mathrm{~g}$ for biochar samples) were extracted for $36 \mathrm{~h}$ in Soxhlet with $100 \%$ toluene. Sample extracts were concentrated to $1 \mathrm{ml}$ with the Syncore parallel Büchi evaporator system (Flawil, Switzerland). The extract was spiked with $20 \mu \mathrm{L}$ of the recovery standard (200 $\mathrm{ng}$ of indeno[1,2,3-cd] fluoranthene in toluene) and concentrated to $1 \mathrm{ml}$ before injecting into GCMS. Sample cleanup of the soil extracts was performed according to Bucheli et al. (2004). Analysis of the 16 US EPA PAHs - naphthalene (NAP), acenaphthylene (ANY), acenaphthene (ANA), fluorene (FLU), phenanthrene (PHE), anthracene (ANT), fluoranthene (FLT), pyrene (PYR), benzo[a] anthracene (BaA), chrysene (CHR), benzo[b]fluoranthene $(\mathrm{BbF})$, benzo $[k]$ fluoranthene $(\mathrm{BkF})$, benzo $[a]$ pyrene $(\mathrm{BaP})$, indeno $[1,2,3,-c d]$ pyrene (IPY), dibenz $[a, h]$ anthracene (DBA), and benzo[ghi]perylene (BPE) - was carried out on an Agilent GC/MS 6890/5973i by on-column injection of $1 \mu \mathrm{L}$ of the extract. The applied chromatographic and mass spectrometric conditions are described in Bucheli et al. (2004). Quantification was carried out using the internal standard method. Isooctane

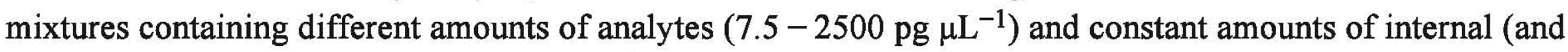

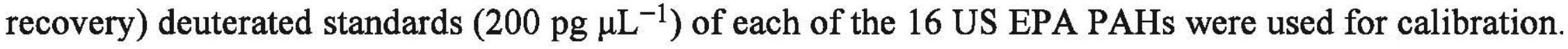

\section{Results and discussion}

\subsection{Determination of PAHs in biochar samples}


Concentrations of each of the 16 US EPA-PAHs are given in Table 2. The total PAH contents ( $\left.\Sigma^{16} \mathrm{PAHs}\right)$ of biochar samples were $2613 \pm 1381 \mu \mathrm{g} \mathrm{kg}^{-1}$ (w-bc), $1774 \pm 402 \mu \mathrm{g} \mathrm{kg}^{-1}$ (ps-bc), $959 \pm 62 \mu \mathrm{g} \mathrm{kg}^{-1}$ (ss-bc), and $15,367 \pm 177 \mu \mathrm{g} \mathrm{kg}^{-1}(\mathrm{kw}-\mathrm{bc})$. Values measured for w-bc, ps-bc, and ss-bc are comparable to those obtained for biochars produced by hydrothermal carbonization or Pyreg reactors (Schimmelpfennig and Glaser 2012; Bucheli et al. 2015). In contrast, the kiln-produced biochar contained significantly greater amount of PAHs than the rest of biochars.

\section{Table 2}

Concentrations of the 16 priority pollutant polycyclic aromatic hydrocarbons defined by the USEPA (EPA PAHs; $\mu \mathrm{g} \mathrm{kg}_{\mathrm{dw}}{ }^{-1}$ ) obta biochar, paper sludge biochar, sewage sludge biochar, and kiln wood biochar (samples w-bc, ps-bc, ss-bc, and kw-bc, respectively 20 , and $40 \mathrm{t}$ biochar ha ${ }^{-1}$ ) incubated during 79 days under greenhouse conditions

\begin{tabular}{|c|c|c|c|c|c|c|c|c|c|c|c|}
\hline \multirow[b]{2}{*}{ Sample } & \multicolumn{5}{|c|}{ Pure samples } & \multicolumn{3}{|c|}{ Soil + w-bc } & \multicolumn{3}{|c|}{ Soil + ps-bc } \\
\hline & $\begin{array}{c}\text { Control } \\
\text { soil }\end{array}$ & $\mathbf{w}-\mathbf{b c}$ & $\begin{array}{l}\text { ps- } \\
\text { bc }\end{array}$ & $\begin{array}{l}\text { ss- } \\
\text { bc }\end{array}$ & $\mathbf{k w}-\mathbf{b c}$ & $10 \mathrm{t} \mathrm{ha}^{-1}$ & $20 \mathrm{tha}^{-1}$ & $40 \mathrm{tha}^{-1}$ & $10 \mathrm{tha}^{-1}$ & $20 \mathrm{tha}^{-1}$ & $40 \mathrm{tha}^{-1}$ \\
\hline NAP & $11(4)$ & $\begin{array}{l}1529 \\
(902)\end{array}$ & $\begin{array}{l}688 \\
(81)\end{array}$ & $\begin{array}{l}489 \\
(29)\end{array}$ & $\begin{array}{l}10,705 \\
(215)\end{array}$ & $24(5)$ & $27(3)$ & $69(21)$ & $9(0)$ & $24(8)$ & $29(2)$ \\
\hline ANY & n.d. & $\begin{array}{l}47 \\
(20)\end{array}$ & $9(0)$ & $\begin{array}{l}10 \\
(0)\end{array}$ & $93(-)$ & $1(0)$ & $1(0)$ & $16(11)$ & n.d. & $3(3)$ & n.d. \\
\hline ANA & $9(12)$ & $\begin{array}{l}274 \\
(37)\end{array}$ & $\begin{array}{l}22 \\
(10)\end{array}$ & $5(1)$ & $\begin{array}{l}61 \\
(49)\end{array}$ & $2(-)$ & $2(1)$ & $8(1)$ & $1(0)$ & $1(0)$ & $30(-)$ \\
\hline FLU & n.d. & $17(6)$ & $\begin{array}{l}18 \\
(1)\end{array}$ & $\begin{array}{l}14 \\
(1)\end{array}$ & $\begin{array}{l}488 \\
(28)\end{array}$ & $1(-)$ & $1(-)$ & $6(3)$ & $1(0)$ & $4(4)$ & $29(19)$ \\
\hline PHE & $10(3)$ & $\begin{array}{l}400 \\
(298)\end{array}$ & $\begin{array}{l}455 \\
(158)\end{array}$ & $\begin{array}{l}169 \\
(25)\end{array}$ & $\begin{array}{l}2526 \\
(154)\end{array}$ & $12(0)$ & $21(2)$ & $269(27)$ & $9(0)$ & $27(12)$ & $23(9)$ \\
\hline ANT & $4(5)$ & $\begin{array}{l}45 \\
(41)\end{array}$ & $\begin{array}{l}65 \\
(13)\end{array}$ & $\begin{array}{l}34 \\
(1)\end{array}$ & $\begin{array}{l}588 \\
(15)\end{array}$ & $1(0)$ & $3(1)$ & $12(6)$ & $1(0)$ & $6(7)$ & $15(-)$ \\
\hline
\end{tabular}




\begin{tabular}{|c|c|c|c|c|c|c|c|c|c|c|c|}
\hline FLT & $5(1)$ & $\begin{array}{l}74 \\
(50)\end{array}$ & $\begin{array}{l}111 \\
(29)\end{array}$ & $\begin{array}{l}40 \\
(3)\end{array}$ & $\begin{array}{l}234 \\
(30)\end{array}$ & $5(0)$ & $10(0)$ & $343(11)$ & $6(1)$ & $10(0)$ & $12(6)$ \\
\hline PYR & $8(1)$ & $\begin{array}{l}156 \\
(76)\end{array}$ & $\begin{array}{l}143 \\
(40)\end{array}$ & $\begin{array}{l}62 \\
(1)\end{array}$ & $\begin{array}{l}297 \\
(31)\end{array}$ & $10(2)$ & $15(2)$ & $282(5)$ & $7(1)$ & $18(9)$ & $11(5)$ \\
\hline $\mathrm{BaA}$ & $1(0)$ & $13(6)$ & $\begin{array}{l}46 \\
(13)\end{array}$ & $\begin{array}{l}19 \\
(2)\end{array}$ & $\begin{array}{l}119 \\
(15)\end{array}$ & $2(0)$ & $3(1)$ & $50(8)$ & $2(1)$ & $13(15)$ & $3(1)$ \\
\hline CHR & $3(1)$ & $23(9)$ & $\begin{array}{l}80 \\
(27)\end{array}$ & $\begin{array}{l}45 \\
(5)\end{array}$ & $\begin{array}{l}170 \\
(26)\end{array}$ & $3(0)$ & $5(1)$ & $128(5)$ & $3(1)$ & $6(1)$ & $9(4)$ \\
\hline $\mathrm{BbF}$ & $2(0)$ & $11(2)$ & $\begin{array}{l}36 \\
(9)\end{array}$ & $\begin{array}{l}13 \\
(3)\end{array}$ & $27(2)$ & $2(0)$ & $3(0)$ & $71(21)$ & $2(1)$ & $4(1)$ & $4(1)$ \\
\hline $\mathrm{BkF}$ & $1(0)$ & $7(3)$ & $\begin{array}{l}14 \\
(4)\end{array}$ & $\begin{array}{l}11 \\
(7)\end{array}$ & $15(1)$ & $1(0)$ & $2(0)$ & $66(19)$ & $2(1)$ & $4(2)$ & $3(1)$ \\
\hline $\mathrm{BaP}$ & $1(0)$ & $6(2)$ & $\begin{array}{l}25 \\
(3)\end{array}$ & $\begin{array}{l}16 \\
(1)\end{array}$ & $40(2)$ & $2(0)$ & $6(5)$ & $30(24)$ & $2(1)$ & $3(-)$ & $5(5)$ \\
\hline IPY & n.d. & $5(-)$ & $\begin{array}{l}27 \\
(0)\end{array}$ & $\begin{array}{l}10 \\
(0)\end{array}$ & $23(1)$ & $2(0)$ & $3(0)$ & $73(52)$ & $2(1)$ & $7(6)$ & $4(2)$ \\
\hline DBA & n.d. & n.d. & $7(2)$ & $\begin{array}{l}7 \\
(-)\end{array}$ & $5(0)$ & n.d. & $1(0)$ & $10(2)$ & n.d. & n.d. & $1(0)$ \\
\hline BPE & $2(0)$ & $11(2)$ & $\begin{array}{l}26 \\
(10)\end{array}$ & $\begin{array}{l}17 \\
(6)\end{array}$ & $22(1)$ & $2(0)$ & $3(0)$ & $82(61)$ & $2(1)$ & $14(16)$ & $5(2)$ \\
\hline $\begin{array}{l}\sum 16 \text { EPA } \\
\text { PAHs }\end{array}$ & $59(4)$ & $\begin{array}{l}2613 \\
(1380)\end{array}$ & $\begin{array}{l}1774 \\
(402)\end{array}$ & $\begin{array}{l}959 \\
(62)\end{array}$ & $\begin{array}{l}15,367 \\
(177)\end{array}$ & $70(4)$ & $107(14)$ & $\begin{array}{l}1515 \\
(107)\end{array}$ & $50(9)$ & $143(81)$ & $161(20)$ \\
\hline NAP/PHE & $\begin{array}{l}1.1 \\
(0.5)\end{array}$ & $\begin{array}{l}3.8 \\
(3.6)\end{array}$ & $\begin{array}{l}1.5 \\
(0.6)\end{array}$ & $\begin{array}{l}2.9 \\
(0.5)\end{array}$ & $\begin{array}{l}4.2 \\
(0.3)\end{array}$ & $2.0(0.4)$ & $1.3(0.2)$ & $0.3(0.1)$ & $1.0(0.0)$ & $0.9(0.5)$ & $1.3(0.5)$ \\
\hline PHE/ANT & $\begin{array}{l}2.5 \\
(3.2)\end{array}$ & $\begin{array}{l}8.9 \\
(10.5)\end{array}$ & $\begin{array}{l}7.0 \\
(2.8)\end{array}$ & $\begin{array}{l}5.0 \\
(0.7)\end{array}$ & $\begin{array}{l}4.3 \\
(0.3)\end{array}$ & $\begin{array}{l}12.0 \\
(0.0)\end{array}$ & $7.0(2.4)$ & $\begin{array}{l}22.4 \\
(11.4)\end{array}$ & $9.0(0.0)$ & $4.5(5.6)$ & $1.5(0.0)$ \\
\hline
\end{tabular}

Number in parentheses indicate standard deviation of two replicates. PAHs are as follows: naphthalene (NAP), acenaphthylen (ANT), fluoranthene (FLT), pyrene (PYR), benzo[a]anthracene (BaA), chrysene (CHR), benzo[b]fluoranthene (BbF), benzo $k$. 
Our result suggests that during the traditional and widely used kiln stacks process, in which feedstock is fitted into the reactor in layers, the pyrolysis process is difficult to be controlled (Hale et al. 2012). The cycle to produce a batch of charcoal by traditional kilns usually takes about 7 days of heating and 5 to 7 days of cooling (Multi Lin 2006). This results in longer residence times (and reaction times) than applied during technical pyrolysis. Those conditions favor not only the heterogeneity of the final char but also the trapping of evolved PAHs in micropores during the incomplete combustion process (Readman et al. 1984; Eganhouse 1987; Hale et al. 2015). Recent scanning electron microscopy analyses (SEM-EDS) confirmed the absence of free pores in kw-bc (De la Rosa et al. 2014). The SEM-EDS distinguished abundance of macropores on the surface of $w-b c$, which agreed with its high specific surface area ( $>400 \mathrm{~m}^{2} \mathrm{~g}^{-1}$; Table 1). In contrast, SEM-EDS analysis of kw-bc presented occluded pores, which contributed to its low specific surface area $\left(<5 \mathrm{~m}^{2} \mathrm{~g}^{-1}\right)$. Schimmelpfennig and Glaser (2012) reported that specific surface areas (SSA) of biochars produced by traditional charcoal stacks were significantly lower than those produced by Pyreg ${ }^{\circledR}$ or wood gasifier systems. However, a direct relation between the SSA and the PAH concentration was not observed, which had been observed previously by Hale et al. (2012).

Bucheli et al. (2015) performed a complete statistical analysis of the influence of different variables in the PAH composition of biochars. Wooden materials, generally enriched in $\mathrm{C}$, yielded higher PAH concentrations than other feedstock which was attributed to the gasification process. The highest PAH levels were measured for kw-bc and $\mathrm{w}-\mathrm{bc}\left(15,367 \pm 177\right.$ and $2613 \pm 1380 \mu \mathrm{g} \mathrm{kg}^{-1}$, respectively; Table 2$)$.

Concerning the PAH species, in all the cases, the dominant compounds were NAP and PHE, contributing with 3969 and $15-26 \%$, respectively, to the $\Sigma^{16}$ PAH concentrations. Other abundant PAHs were FLU, ANT, and PYR. A low contribution of heavy PAHs was observed; particularly, the abundance of DBA was negligible. Nevertheless, 
taking into account that six-ring PAHs are relatively stable, mutagenic, and carcinogenic, the presence of some of them (mainly BaP, IPY, and BPE) in all biochars should not be neglected.

Wiedemeier et al. (2015) hypothesized that low-molecular-weight PAHs, and specially NAP, are dominating at low pyrolysis temperatures $\left(\leq 500^{\circ} \mathrm{C}\right)$. However, taking into account that pyrolysis conditions for w-bc, ps-bc, and ss-bc were practically similar, the values measured for the ratios of low- to high-molecular-weight PAHs [(NAP + $\mathrm{ANY}+\mathrm{ANA}+\mathrm{FLU}+\mathrm{PHE}+\mathrm{ANT}+\mathrm{FLT}+\mathrm{PYR}) /(\mathrm{BaA}+\mathrm{CHR}+\mathrm{BbF}+\mathrm{BkF}+\mathrm{BaP}+\mathrm{IPY}+\mathrm{DBA}+\mathrm{BPE})]$ of these three samples (28.6-39.2 for w-bc, 5.6-6.0 for ps-bc, and 5.9-6.2 for ss-bc)) may also be related to the nature of the feedstock and not only to the pyrolysis temperature. This finding is supported by the values calculated for kw-bc (ranging from 33.0 to 38.3 , they) which were similar to the other wood-derived biochar w-bc. The PHE/ANT ratio of pure biochars varied from $4.3 \pm 0.3(\mathrm{kw}-\mathrm{bc})$ to $8.9 \pm 10.5$ (w-bc), within the characteristic range reported for pyrolytic sources (from 1 to 10; Yunker et al. 2002). Schimmelpfennig and Glaser (2012) have used successfully the NAP/PHE ratio by to differentiate biochar materials. In our study, the NAP/PHE ratios were relatively homogenous. However, those of wood-derived biochars ( $3.8 \pm 3.6$ to $4.2 \pm 0.3)$ were higher, but not statistically significant, than those from paper sludge and sewage sludge biochars $(1.5 \pm 0.6$ to $2.9 \pm 0.5)$.

\subsection{PAH maximum threshold levels of biochars}

Figure 1 compares the values obtained for the sum of the 16 US EPA PAHs ( $\Sigma^{16}$ PAHs) on the four biochars with the maximum allowed thresholds of total PAHs suggested by the IBI and the EBC, respectively.

Fig. 1

Comparison of mean values of the summed 16 priority pollutant polycyclic aromatic hydrocarbons defined by the USEPA (EPA-PAHs) in the biochar samples and the threshold values for biochar material according to the European Biochar Certificate (EBC) and International Biochar Initiative (IBI) and for amended soils according to the German and Swiss legislations 


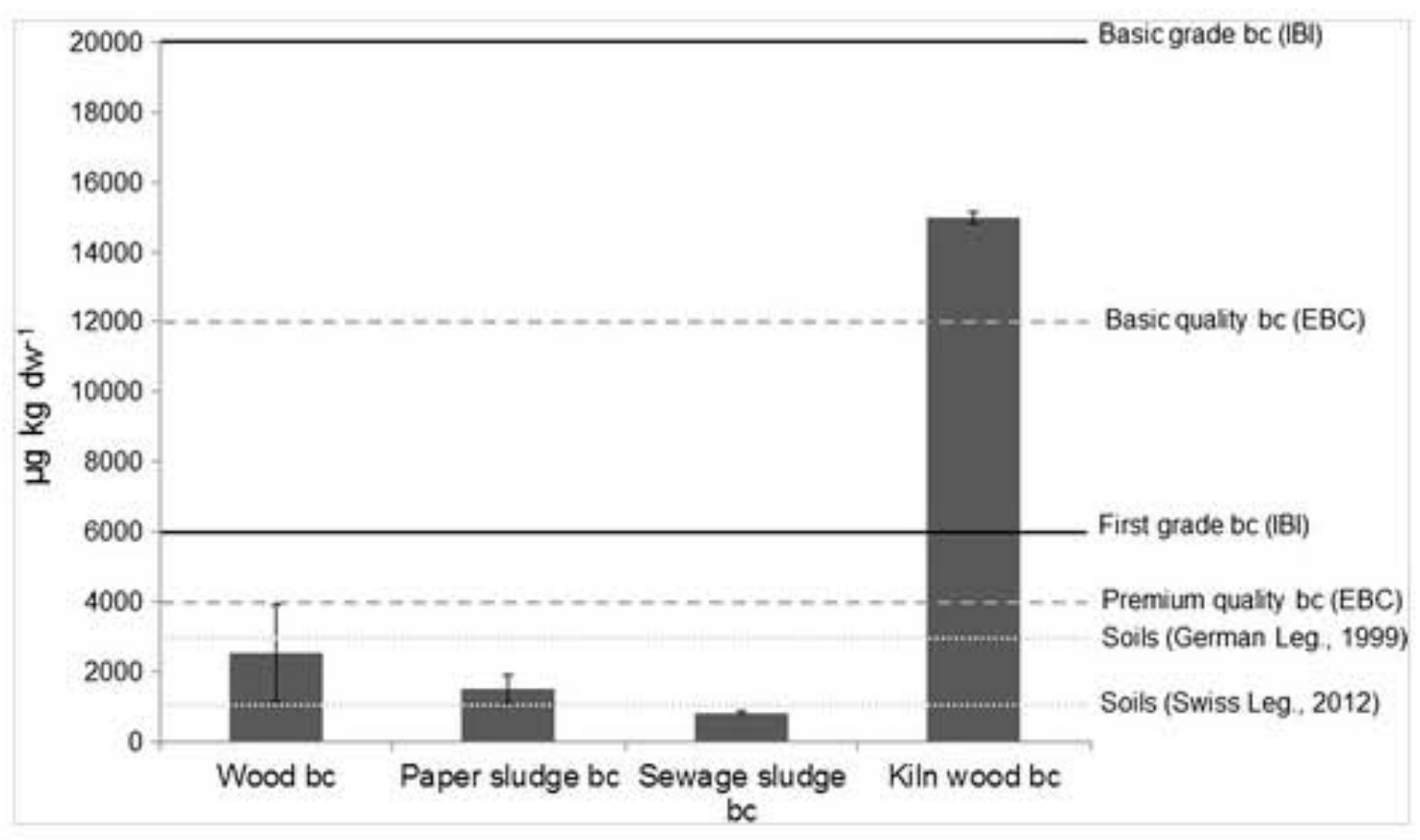

Values of $\Sigma^{16}$ PAHs of samples w-be, ss-bc, and ps-be were $2613 \pm 1380,1774 \pm 402$, and $959 \pm 62 \mu \mathrm{g} \mathrm{kg}{ }^{-1}$, respectively. All of them are considerably below the allowed thresholds; thus, they can be considered as premium quality biochars which can be regularly applied to arable soils according to the Swiss and German legislation (Bucheli et al. 2015; German Legislation 1999; Swiss legislation 2012). In contrast, the $\Sigma^{16}$ PAH level of kw-be $\left(15,367 \pm 177 \mu \mathrm{g} \mathrm{kg}^{-1}\right)$ exceeds considerably the maximum allowed thresholds set for premium quality biochar. Consequently, this material should not be used for agricultural purposes or as soil ameliorant. According to previous studies, only part of PAH load introduced in the soil with biochar will be bioavailable and pose an ecotoxicological risk (Chen and Yuan 2011; Hale et al, 2012). However, further knowledge concerning PAH degradation and availability in biochar is necessary, especially at this early stage of production and commercialization of biochar in which product quality and safety are essential for its reputation and successful development. 


\subsection{Determination of PAHs in incubated soils}

Concentration of the 16 US EPA PAHs and its sum in the incubated soils are shown in Table 2. The latter obtained for unamended soil $\left(59 \pm 4 \mu \mathrm{g} \mathrm{kg}^{-1}\right)$ was significantly lower than those reported for agricultural soils from the Seville area $\left(\geq 89.5 \mu \mathrm{g} \mathrm{kg}^{-1}\right.$ ) by Morillo et al. (2008). This low concentration classifies our soil as noncontaminated with PAHs (Wilcke 2007).

As expected, the application of 10, 20, and $40 \mathrm{t} \mathrm{ha}^{-1}$ of four different biochars resulted in different concentrations of PAHs (see Table 2). Biochar addition of $10 \mathrm{tha}^{-1}$ caused a low or no significant increase of the $\Sigma^{16}$ PAHs for w-bc and ps-bc. However, in ss-bc and especially kw-bc-amended soils, the content of the $\Sigma^{16}$ PAHs increased drastically. Figure 2 shows a comparison of the determined concentrations of the $\Sigma^{16}$ PAHs vs. the theoretically predicted values at a logarithmic scale. The expected concentrations of PAHs in the biochar-amended soils have been calculated by adding the amount of PAHs in the uncontaminated control soil to the amount of PAHs which was added with the applied biochar. This figure confirms that the determined concentrations for the soils amended with $10 \mathrm{tha}^{-1}$ of w-bc and ps-bc were lower than expected. Figure 3 depicts the comparison between measured and expected results for the concentrations of NAP, ANY, FLT, BkF, and $\Sigma^{16}$ PAHs for amendments of 10,20 , and $40 \mathrm{t} \mathrm{ha}^{-1}$ (Fig. 3a-c, respectively). NAP, ANY, FLT, and BkF have been selected for being representative of light and heavy PAHs from the 16 quantified PAHs. A good correlation is shown for soils amended with $10 \mathrm{tha}^{-1}$ of ssbc and ps-bc $\left(r^{2}=0.9912\right.$ and 0.9718 , respectively; $p \leq 0.005$; Fig. 3a). In contrast, the experimental value of $\Sigma^{16} \mathrm{PAHs}$ for kw-bc was one order of magnitude higher than predicted (Fig. 2). This lack of correlation of kw-bc was observed for all the PAHs selected for Fig. 3a $\left(r^{2}=0.5224\right)$. Possibly, this is attributed to the heterogeneity of this biochar, which may represent a more critical factor at lower doses.

Fig. 2

Logarithmic (base 10) transformation of the experimental values of the $\Sigma^{16} \mathrm{PAHs}$ vs. the theoretically predicted values of the $\Sigma^{16} \mathrm{PAHs}$ for each amendment dose and type of biochar applied 


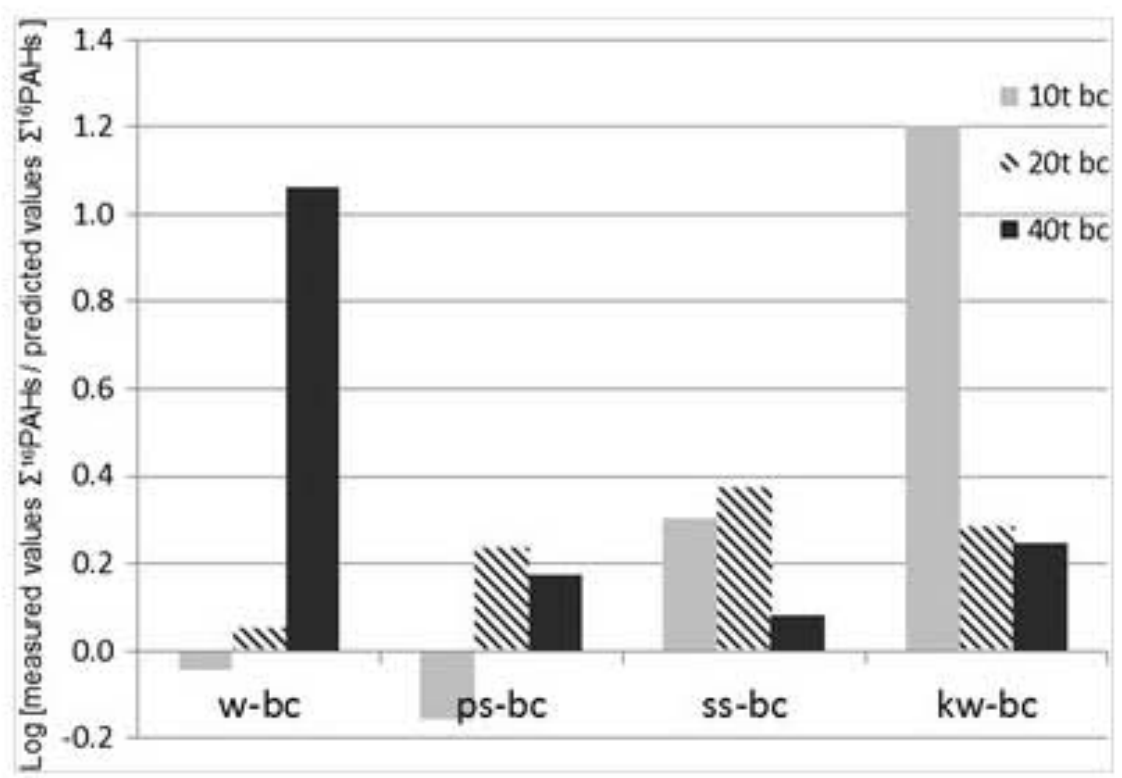

Fig. 3

Correlation between experimental and predicted concentrations of NAP, ANY, FLT, BkF, and $\Sigma^{16} \mathrm{PAHs}\left(\mathrm{mg} \mathrm{kg}^{-1}\right)$ for amendments of a $10 \mathrm{tha}^{-1}, \mathrm{~b} 20 \mathrm{tha}^{-1}$, and c $40 \mathrm{tha}^{-1}$

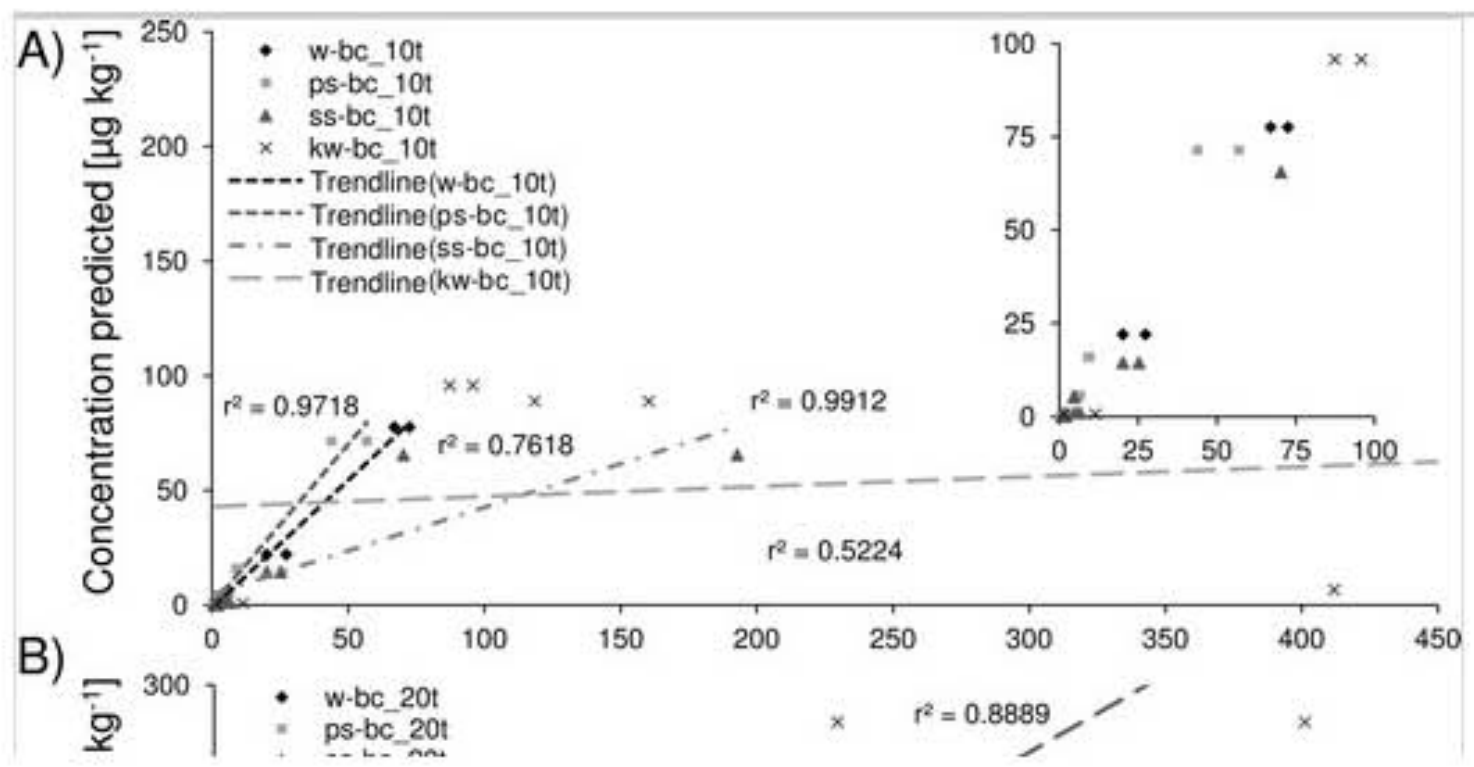



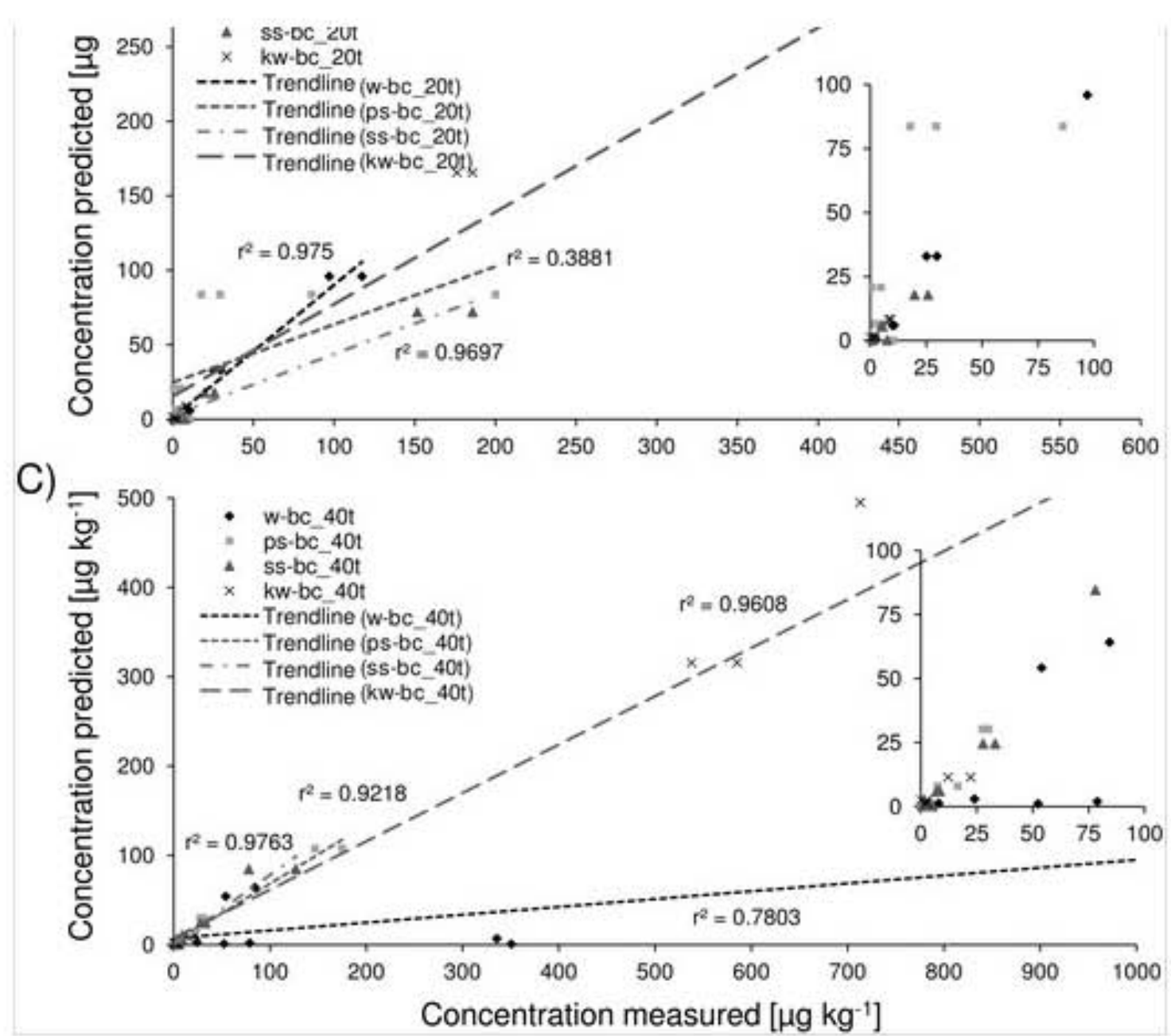

Additions of $20 \mathrm{tha}^{-1}$ biochar increased PAH concentrations in all the cases. The values ranged from $107 \pm$ $14 \mu \mathrm{g} \mathrm{kg}^{-1}$ for $\mathrm{w}$-be to $537 \pm 325 \mu \mathrm{g} \mathrm{kg}^{-1}$ for $\mathrm{kw}$-bc. Measured data of the $\Sigma^{16} \mathrm{PAHs}$ were greater than the predicted values (Fig. 2). Figure $3 \mathrm{~b}$ indicates a better correlation between experimental and predicted data for the samples with a dose of $20 \mathrm{tha}^{-1}$ biochar. From a methodological point of view, the increase of the biochar dose from 10 to $20 \mathrm{t} \mathrm{ha}^{-1}$ seemed to minimize the effect of the heterogeneity. Experimental values of $\Sigma^{16} \mathrm{PAHs}$ of ps-bc were significantly higher than predicted. This fact was mainly due to a higher amount of low-weight PAH compounds (NAP, PHE, PYR) leading to a poor correlation $\left(r^{2}=0.3881 ; p \leq 0.01\right)$. 
Biochar additions of $40 \mathrm{t} \mathrm{ha}^{-1}$ caused very diverse effects on the total amount of PAHs. Ps-bc and ss-bc additions to soil increased the $\Sigma^{16}$ PAHs in line with the biochar loaded. Kw-bc amendment increased the $\Sigma 16$ PAHs (not significantly) compared to the addition of $20 \mathrm{t} \mathrm{ha}^{-1}$ (Table 2). In the case of amendment with $40 \mathrm{t} \mathrm{ha}^{-1}$ of w-bc, $\Sigma^{16}$ PAH (1515 $\pm 107 \mathrm{mg} \mathrm{kg}^{-1}$ ) was one order of magnitude greater than predicted (Fig. 2). The lack of correlation between measured and predicted values in this sample was more drastic for heavy PAHs (Fig. 3c). Similarly to $\mathrm{kw}-\mathrm{bc}$, the major differences were probably due to a nugget effect and heterogeneity of biochar samples derived from wood (with regard to the $\Sigma^{16} \mathrm{PAHs}$, w-bc showed approx. $50 \%$ relative standard deviation for $\Sigma^{16}$ PAHs). Results obtained for $\mathrm{w}-\mathrm{bc}$ and, especially, kw-bc point to the necessity of applying not only appropriate methodology and protocols over the whole experimental process, including production, homogenization, and handling of biochars, but also soil sampling, PAH extraction, and PAH analysis.

NAP and PHE were the most abundant PAHs in all biochar-amended soils with the exception of two cases. High levels of FLT and PYR (343 \pm 11 and $282 \pm 5 \mu \mathrm{g} \mathrm{kg}^{-1}$, respectively) were measured for the sample soil $+\mathrm{w}$-bc $40 \mathrm{t} \mathrm{ha}^{-1}$; in addition, sample soil + kw-bc $10 \mathrm{t} \mathrm{ha}^{-1}$ was dominated by FLT, PHE, and PYR (456 $\pm 63,417 \pm 59$, and $368 \pm 56 \mu \mathrm{g} \mathrm{kg}^{-1}$, respectively). As mentioned previously, results of these two samples showed a lack of correlation when compared with the predicted values. In addition, both samples contained a greater total amount of PAHs than the rest of the samples from their series. Most tentatively, this is related to their heterogeneity and probable low representativeness of the biochar sample.

\section{Conclusions}

Our study showed that pyrolysis-gasification reactors, in which syngases and tar oils are removed, are more favorable with respect to PAH contents of the final product than the carbonization in traditional kilns. According to the known threshold levels for PAHs, our studies indicate that care has to be taken if the studied biochar produced by kilns is used as soil amendment. Unique and unambiguous threshold levels of persistent pollutants (including PAHs) are strictly needed and must be established by consensus. 
Being conscious of the limitations of incubation experiments which make extrapolations to field challenging, especially in strongly seasonal climates, the results of this incubation study indicated that initial PAH concentrations of biochar may not be transferred to the soil in a linear manner or maintained as such within the soil after starting incubation. Accordingly, a uniform behavior of PAHs in soils amended with different biochars cannot be assumed. Although our study could not discern specific mechanism responsible for the lack of accordance between the concentrations of PAHs in soils with mass balance calculations, it is clear that a better understanding of the soil-plant-biochar interactions is required to obtain reliable predictions of potential hazardous impacts of biochar application. In addition, the homogeneity of biochars and the representativeness of sampling for biochar-amended soils for future legislation guidelines and experimental settings should be specially taken into account to properly assess PAHs in biochar-amended soils, which is mandatory for a quality biochar application. Investigation of PAH levels and its availability on vegetation biomass cultivated on biochar-amended soils should be the next crucial objective.

\section{Acknowledgments}

The Marie Skłodowska Curie actions of the European Union's Seventh Framework People Programme (REA grant agreement $n^{\circ}$ PCIG12-GA-2012-333784-Biocharisma project) and the Spanish Ministry of Economy and Competitiveness (MINECO) (project PCGL2012-37041) are thanked for the financial support of the present study. Ph.D. J.M de la Rosa thanks the COST Action TD1107 "Biochar as an option for sustainable resource management” for funding his Short-Term Scientific Mission at Agroscope ART (Zurich, Switzerland). The European Biochar Network (Biochar as option for sustainable resource management-COST action TD1107) and Bodegas Torres (Spain) are acknowledged for providing the biochar samples

\section{References}

Brennan A, Moreno Jiménez E, Alburquerque JA, Knapp CW, Switzer C (2014) Effects of biochar and activated carbon amendment on maize growth and the uptake and measured availability of polycyclic aromatic 
hydrocarbons (PAHs) and potentially toxic elements (PTEs). Environ Pollut 193:79-87

Bucheli TD, Blum F, Desaules E, Gustafsson Ö (2004) Polycyclic aromatic hydrocarbons, black carbon, and molecular markers in soils of Switzerland. Chemosphere 56:1061-1076

\section{Bueheli TD, Baehmann HJ, Blum F, Bürge D, Giger R, Hilber I, Keita J, Leifeld J, Sehmidt IP (2014) On the hetegeneity of biochar andeonsequenes for its representative sampling. J Anal Appl Pyrol 107:25-30 AQ6}

Bucheli TD, Hilber I, Schmidt HP (2015) Polycyclic aromatic hydrocarbons and polychlorinated aromatic compounds in biochar. In: Lehmann J, Joseph S (eds) Biochar for environmental management, 2nth edn. Earthscan, London

Chen BL, Yuan MX (2011) Enhanced sorption of polycyclic aromatic hydrocarbons by soil amended with biochar. J Soils Sediments 11:62-71

De la Rosa D (1984) Catálogo de suelos de Andalucía. Monografías del Medio Ambiente 274 pp. Servicio de publicaciónes y B.O.J.A. de la Junta de Andalucía. Seville, Spain. ISBN: 84-7595-005-1. $\mathrm{http}: / / \mathrm{www}$.juntadeandalucia.es/medioambiente/site/portalweb/menuitem.7e1cf46ddf59bb227a9ebe205510e1ca/? vgnextoid=0799bf6d57857010 VgnVCM1000000624e50aRCRD\&vgnthirdoid=fdb4760edc7a7010 VgnVCM1000000

De la Rosa JM, Paneque M, Miller AZ, Knicker H (2014) Relating physical and chemical properties of four different biochars and their application rate to biomass production of Lolium perenne on a Calcic Cambisol during a pot experiment of 79 days. Sci Total Environ 499:175-184

Estrada de Luís IB, Gómez Palacios JM (2013) European Union (EU) End of waste regulation: requirements for input materials and compost quality for sludge and other biodegradable wastes. J Res Sci Technol 10(3), 
EBC 2012. European Biochar Certifieate-guidelines for a sustainable production of bioehar. European Bioehar Foundation (EBC), Arbaz, Switzerland p. 18 http:/Www.european-bioehar.org/en/download (aecessed 22.12.14)This reference could be replaced by:

EBC 2012- European Biochar Certificate - Guidelines for a Sustainable Production of Biochar. European Biochar Foundation (EBC), Arbaz, Switzerland. http://www.europeanbiochar.org/en/download. Version 6.1 of 19th June 2015, DOI: 10.13140/RG.2.1.4658.7043

ECR (2006) European Commission Regulation No 1881/2006 of 19th December 2006. Setting maximum levels for certain contaminants in foodstuffs, available at: http://eurlex.europa.eu/LexUriServ/LexUriServ.do? uri=OJ:L : 2006:364:0005:0024:EN:PDF

Eganhouse RP (1987) Molecular markers in environmental geochemistry. American Chemical Society, Washington DC

Fabbri D, Rombola AG, Torri C, Spokas KA (2013) Determination of polycyclic aromatic hydrocarbons in biochar and biochar amended soil. J Anal Appl Pyrol 103:60-67

Fagernäs L, Kuoppala E, Tiilikkala K, Oasmaa A (2012) Chemical composition of birch wood slow pyrolysis products. Energ Fuel 26:1275-1283

Gerlach A, Schmidt HP (2011) The use of biochar in cattle farming. J. for terrior-wine \& biod. http://www.ithaka-journal.net/pflanzenkohle-in-der-rinderhaltung?lang=en (accessed 26.10.14)

German legislation (1999) Bundes - Bodenschutz- und Altlastenverordnung BbodSchV 
González-Pérez JA, Almendros G, De la Rosa JM, González-Vila FJ (2014) Appraisal of polycyclic aromatic hydrocarbons (PAHs) in environmental matrices by analytical pyrolysis (Py-GC/MS). J Anal Appl Pyrol 109:1-8

Hale SE, Lehmann J, Rutherford D, Zimmerman AR, Bachmann RT, Shitumbanuma V, O'Toole A, Sundqvist KL, Arp HPH, Cornelissen G (2012) Quantifying the total and bioavailable polycyclic aromatic hydrocarbons and dioxins in biochars. Environ Sci Technol 46:2830-2838

Hale SE, Cornelissen G, Werner D (2015) Sorption and remediation of organic compounds in soils and sediments by (activated) biochar. In: Lehmann J, Joseph S (eds) Biochar for environmental management, 2nd edn. Earthscan, London

Hilber I, Blum F, Leifeld J, Schmidt HP, Bucheli T (2012) Quantitative determination of PAHs in biochar: a prerequisite to ensure its quality and safe application. J Agric Food Chem 60:3042-3050

IBI (2013) Standardized product definition and product testing guidelines for biochar that is used in soil. International Biochar Initiative, p. $48 \mathrm{http}: / /$ www.biocharinternational.org/sites/default/files/IBI_Biochar_Standards_V1.1.pdf (accessed 26.04.15)

IUSS Working Group WRB (2014) World Reference Base for Soil Resources 2014. International soil classification system for naming soils and creating legends for soil maps. World Soil Resources Reports No. 106. FAO, Rome

Keiluweit M, Kleber M, Sparrow MA, Simoneit BRT, Prahl FG (2012) Solvent-extractable polycyclic aromatic hydrocarbons in biochar: influence of pyrolysis temperature and feedstock. Environ Sci Technol 46:9333-9341

Ledesma EB, Marsh ND, Sandrowitz AK, Wornat MJ (2002) Global kinetic rate parameters for the formation 
of polycyclic aromatic hydrocarbons from the pyrolysis of catechol, a model compound representative of solid fuel moieties. Energ Fuel 16:1331-1336

Li H, Qu R, Li C, Guo W, Han X, He F, Ma Y, Xing B (2014) Selective removal of polycyclic aromatic hydrocarbons ( PAHs ) from soil washing effluents using biochars produced at different pyrolytic temperatures. Bioresour Technol 163: 193-198

Liu L, Chen P, Sun M, Shen G, Shang G (2014) Effect of biochar amendment on PAH dissipation and indigenous degradation bacteria in contaminated soil. J Soils Sediments 15:313-322

Morillo E, Romero AS, Madrid L, Villaverde J, Maqueda C (2008) Characterization and sources of PAHs and potentially toxic metals in urban environments of Sevilla (Southern Spain). Water Air Soil Pollut 187:41-51

Mudarra Gómez JL (1988) Reconocimiento de los suelos de la comarca del Aljarafe (Sevilla). Consejo Superior de Investigaciones Científicas, Seville

Multi Lin JC (2006) Development of a high yield and low cycle time biomass char production system. Fuel Process Technol 87:487-495

Ogawa M, Okimori Y (2010) Pioneering works in biochar research, Japan. Aust J Soil Res 48:489-500

Oleszczuk P, Jośko I, Kuśmierz M (2014) Biochar properties regarding to contaminants content and ecotoxicological assessment. J Hazard Mater 260:375-382

Readman JW, Mantoura RF, Rhead MM (1984) The physico-chemical speciation of polycyclic aromatic hydrocarbons (PAH) in aquatic systems. Fresenius Z Anal Chem 319:126-131 
Rogovska N, Laird D, Cruse RM, Trabue S, Heaton E (2012) Germination tests for assessing biochar quality. J Environ Qual 41:1014-1022

Schimmelpfennig S, Glaser B (2012) One step forward toward characterization: some important material properties to distinguish biochars. J Environ Qual 41:1001-1013

Swiss legislation (2012). Ordinance related to impacts on soils. http://www.admin.ch/ch/d/sr/c814_12.html ; July 1, 1998 (actualized June 1, 2012). Accessed: April 11, 2015

US EPA (2002) Polycyclic organic matter, Washington, DC: Environmental Protection Agency, available at: http://www.epa.gov/ttn/atw/hlthef/polycycl.html .

Veihmeyer FJ, Hendriekson AII (1949) Methods of measuring field eapaeity and wilting pereentages of soils. Soil Sei $68: 75-94$

$\mathrm{AQ7}$

Wang Z, Zheng H, Luo Y, Deng X, Herbert S, Xing B (2013) Characterization and influence of biochars on nitrous oxide emission from agricultural soil. Environ Pollut 174:289-296

Wiedemeier D, Brodowski S, Wiesenberg G (2015) Pyrogenic molecular markers: linking PAH with BPCA analysis. Chemosphere 119:432-437

Wilcke W (2007) Global patterns of polycyclic aromatic hydrocarbons (PAHs) in soil. Geoderma 141:157-166

Yunker MB, Macdonald RW, Vingarzan R, Mitchell RH, Goyette D, Sylvestre S (2002) PAHs in the Fraser river basin: a critical appraisal of PAH ratios as indicators of PAH source and composition. Org Geochem $33: 489-515$ 
Zhao L, Xinde C, Mašek O, Zimmerman A (2013) Heterogeneity of biochar properties as a function of feedstock sources and production temperatures. J Hazard Mater 256-257:1-9 